\title{
19. People's Climate Case - families and youth take the EU to court over its failure to address the climate crisis
}

\author{
Gökşen Şahin
}

We wouldn't take the European Union to court if our families, friends, homes, traditions and the future of our children weren't at stake. For us, climate change is no longer about high-level diplomacy or negotiations. It is happening to us. (From a joint letter of plaintiffs of the People's Climate Case to the European Environment

Ministers)

They are farmer, forester, hotel owner and animal herder families from Portugal, Italy, France, Germany, Romania, Kenya and Fiji, and a youth association representing the indigenous Saami youth in Sweden. In 2018, they sued the European Parliament and the European Council over the inadequacy of the European Union's (EU) 2030 climate target to tackle the climate crisis and to protect their lives, livelihoods and fundamental rights.

How did they come together? What does a Fijian family with three kids have in common with young Saami reindeer herders in Sweden? And a Kenyan farmer with a German islander? The answer is clear. They all demand climate justice. They are not the ones who caused the climate breakdown but the ones suffering from it. Devastating impacts of the climate crisis are progressing even faster than the scientists have predicted. For these families and millions of other people hit by climate change, every day brings a new fight for survival. And yet the governments, even the EU who pretends to be a global climate champion, are failing to protect them.

These families are not alone. They are a part of global climate litigation movement. Today, citizens across the world are holding their governments accountable for their inadequate climate policies and challenging fossil fuel companies for deepening the climate crisis. Climate change litigation is becoming an important tool to tackle climate change and the violation of human rights at the same time.

In the landmark People's Climate Case, the plaintiffs argue that climate protection is a duty of care that is not determined by political discretion but an 
objective one. Therefore, the EU has a legal obligation to simply do what it can to protect citizens and their rights, while also avoiding further harm.

This legal obligation is not only coming from the European treaties and laws but also an international one. By adopting the Paris Agreement in 2015, the world, including EU countries, decided to pursue efforts to limit temperature rise to $1.5^{\circ} \mathrm{C}$. As a consequence, they also accept to take pledges that "reflect the highest possible ambition". However, the EU's climate target, which was set in 2014 to reduce emissions by at least 40 per cent by 2030, has not been amended since the Paris Agreement. It is contributing to a $3^{\circ} \mathrm{C}$ temperature increase by the end of the century and definitely far from being the most ambitious climate target that the EU can take.

These families, as well as the Saami youth, whose lives depend on nature, are already severely suffering from the consequences of climate change. Some of them tried to realize adaptation projects to save their lands but the impacts got worse much faster than expected. Today, they have reached a point where their health situation and their lands cannot adapt to the climate crisis anymore. They need URGENT climate action.

The anger, fear and disappointment that they feel due to governments' failure to tackle the climate crisis have transformed them from being ordinary peasants, hotel owners and herders into activists of all ages who stand up and fight for their rights. Today, in court, they are not asking financial compensation for their losses. They ask courts to order the European decision-makers to make better climate legislation to protect citizens, their fundamental rights, and future generations. Outside of court, they join the youth and citizens to demand climate justice.

As one of the plaintiffs, 73-year-old French lavender farmer Maurice Feschet said: "We have lived on this land for six generations. My son Renaud is the first generation to start other businesses, as the lavender farming can no longer guarantee sufficient income for the whole family. At my age, besides joining climate marches with young people, this legal case is the only thing that I can do to protect my children and grandchildren. As a citizen, I will keep turning to the courts as politicians fail to deliver the needed climate action".

These families and youth are asking the courts to protect their human rights when the governments fail to do so. They are vanguards in the fight for a safe future, just like millions of other people advocating, mobilizing, boycotting, and striking for climate. They are among millions who lead on climate action. They prove to us that US social activist Grace Lee Boggs was right when she said, "we are the leaders we've been looking for".

Now, with more and more climate cases in courts, millions of young people taking to the streets, businesses and cities taking action to reduce emissions, we see that a change is coming in Europe - a change led by youth and people who are moving from front line of climate change to the forefront of climate action. 
Thanks to their efforts and pressure, the European Parliament has declared the Climate Emergency in 2019 and currently calls on the EU to increase its 2030 climate target to $60 \%$. EU Member States are discussing to enhance the climate target before the end of 2020. This is the story of families and the indigenous youth who contributed to the momentum for a change in Europe.

\section{FROM THE FRONT LINE OF CLIMATE CHANGE TO THE FOREFRONT OF CLIMATE ACTION}

Sanna Vannar is a 23-year-old Saami reindeer herder from Jokkmokk, Sweden. She represents the Saami Youth Association in the People's Climate Case. For the Saami people, who live in the harsh Arctic environment, their entire way of life is strongly connected to nature. For centuries, they have adapted, persevered and survived. Now, they feel endangered because of climate change.

Everything that surrounds Sanna and the Sami people is changing: wildfires hitting the Saami grazelands, reindeer dying due to a lack of food, and emotional stress caused by the uncertainty of climate conditions are becoming unbearable for the Sami youth. Sanna explains: "Already hundreds of Saami words describing different types of snow are no longer used. Our language is changing, but so is all the traditional knowledge. We cannot predict where to find fish, which signs to read in nature anymore. We are even losing the traditional knowledge of our elders, like knowing how the weather will change by reading the signs. Because nobody can read the signs of nature anymore".

Today, the indigenous Saami people are living the consequences of governments' lack of climate action. They deserve to be heard in court but also in decision-making processes, as their indigenous knowledge on land and nature provides invaluable solutions to the climate crisis.

In the People's Climate Case, the Saami youth are accompanied by many other families from Europe who are affected in many different and peculiar ways. Portuguese Armando Carvalho and his son have dedicated their lives to showcasing sustainable forest management practices by replacing pine and eucalyptus trees with local species such as oak and chestnut. For 20 years, they have invested in their forested land in the centre of Portugal. In 2017, Portuguese wildfires, which are scientifically associated with climate change-induced heatwaves and droughts, hit all their forested land. The family home was also surrounded by flames, and his agricultural machinery and garage were damaged by the fire. Armando and his son were lucky to survive the forest fire, but they have never forgotten it. They are now investing in rehabilitation of their forested land, but it is nevertheless impossible to estimate if and when they will again have a mature forest, given the risk scenarios of climate change in Portugal. Having once lived this disaster, they are now trying to avoid the worst for others. 
The Sendim family have owned a family farm in Portugal for more than 100 years. Alfredo Sendim, a farmer for 30 years, created a farmers' cooperative on his land and today more than 35 families work and depend on this land. For a decade, the impacts of climate change have been getting worse in the region, and land use and working conditions are becoming increasingly difficult due to rising temperatures and lack of water. Every year, they are investing more to continue farming activities, while their income from the land continues to decrease. All families who depend on this land are asking themselves the same questions: "When to leave our land?" "Where to go?" Therefore, Alfredo Sendim and the Caixeiro family who are members of the farmers' cooperative joined this climate case to alert the EU courts to the fact that climate protection is no longer a political or purely diplomatic issue. It is about protecting citizens lives, livelihoods and rights in Europe.

Maike and Michael Recktenwald have built their family, hotel and restaurant business from scratch in 20 years on Langeoog island in Germany. Today, their livelihood is at risk of disappearing due to the increasing risk of the North Sea breaking through sand dunes into their freshwater reservoir. Scientific studies already show that short-term emission reduction is critical, especially with regard to sea level rise. When it comes to reducing emissions to protect their island, every minute counts. They believe that activating jurisdiction is the only way to hold governments accountable for their inaction and provide a better future for their son.

In the Italian Alps, Giorgio Elter owns a small bed \& breakfast hotel, which is fully dependent on the famous ice-climbing opportunities in the region. The changes in temperature are making the ice climbing dangerous, which severely affects the Elters' family business, as well as many others in the region. He explains: "Today, I can hardly take care of my family and can't guarantee a safe future for my daughters. We are not responsible for the climate breakdown but we are the ones who suffer. Just like any parent, I am trying to protect the future of my children".

The European plaintiffs of the People's Climate Case have also joined forces with the Guyo family from Kenya and the Qaloibau family from Fiji to demonstrate that the EU's climate inaction has devastating consequences in the Global South. Just like the climate crisis, this growing climate litigation movement knows no borders.

\section{GLOBAL SOUTH JOINS EUROPEANS TO SEEK STRONGER CLIMATE MEASURES}

The People's Climate Case is the first climate case to claim that the EU's failure to address the climate crisis has effects beyond its borders, and people living outside Europe are also entitled to the EU fundamental rights to health, 
occupation, property and equal treatment. Two families from the Global South challenge the EU for the equal protection of their human rights.

The Qaloibau family, with their three children, live in a village on the island of Vanua Levu in the Republic of Fiji. Like most of Fiji's rural communities, the family relies on marine resources and subsistence farming. Petero Qaloibau explains: "In 2002, houses are blown away in my village due to hurricanes. My small shop is destroyed during Cyclone Thomas in 2010. Tropical Cyclone Winston hit Fiji with a wind speeds of more than $230 \mathrm{~km} / \mathrm{hour}$ in 2016 and our farm was inundated with sea water almost $200 \mathrm{~m}$ inland. Today, my mind is set: I'm affected by climate change. Science confirms it and the EU who is supposed to be a climate leader is failing us".

Petero Qaloibau is not the only Pacific Islander who asks the EU to ramp up climate action. In 2019, the president of Marshall Islands, Hilda Heine, and Prime Minister of Fiji, Frank Bainimarama, wrote a joint letter to the EU leaders. They said: "Every day our people, the people of island states, are confronted with the harsh realities of climate change. We are reaching a critical juncture in the fight against this change and the European Union should help us by raising its own climate ambition". ${ }^{1}$

The landmark report of Intergovernmental Panel on Climate Change (IPCC), Global Warming of $1.5^{\circ} \mathrm{C}$, made it crystal clear that we have far less time available than we thought to turn the tide. Only short-term action can effectively preserve life on small island states. And EU leaders must take the responsibility and do their part to step up short-term climate action.

The Guyo family, with their five children, live in a village in Marsabit County, Northern Kenya, close to the Ethiopian border. All members of the family are suffering from extreme heatwaves, longer and more severe droughts and lack of water. Children are particularly vulnerable as they need to walk a $1.5 \mathrm{~km}$ distance to school every day. During heatwaves when the temperature is above $40-45^{\circ} \mathrm{C}$, kids suffer from headaches, disturbed sleep and other heat-related health problems. On top of this, their right to education is also violated as they cannot attend school due to there being no shade on their route to school.

Roba Guyo explains the complexity of the climate crisis: "We have seen all kind of sufferings related to climate change. We used to harvest all season round. Our granary was always full and we were able to feed our animals with what we produce from our farm. We are not used to this drought where our animals die and our farmland dries up. These days, there are a lot of people and livestock who are fleeing from droughts".

Dima Guyo, mother of five children adds: "Climate change is mostly women's problem. In Africa, women take care of families, livestock and kids. When I need to walk further to get water for my kids, I don't have time to cook or even eat something. If I walk that distance under extreme temperatures, 
I need to deal with a lot of health problems. Given the severity of these consecutive droughts, I don't know if I will survive from the one that will hit us next, or the year later. I don't know in which conditions my kids will live. I just want to go to court, to look in the eyes of those decision-makers, and ask: why are you doing this to my children?"

Devastating impacts of climate change are borne disproportionately by the most vulnerable, including the rural poor, women and indigenous populations. Both in Europe and the Global South, farming communities who depend on nature, indigenous people, women and children are more exposed to the consequences of climate change. The report published in June 2019 by Philip Alston, the UN Special Rapporteur on extreme poverty and human rights, clearly explains the human rights impacts of the climate crisis: "Climate change threatens the future of human rights and risks undoing the last fifty years of progress in development, global health, and poverty reduction". It is not surprising to see all different communities from Europe and the Global South coming together in the People's Climate Case to seek to force governments to adopt more stringent climate regulation to protect our common future.

\section{OPENING COURT DOORS TO THE PEOPLE AFFECTED BY CLIMATE CHANGE}

The People's Climate Case is novel on many different levels, even though a legal victory is by no means certain. This case is not only putting the EU's failure to provide necessary climate protection in the spotlight but also its blockage to access to justice for citizens and non-governmental organizations (NGOs) on environmental issues.

According to the European Courts' interpretation of the Treaty of Functioning of the EU since the 1960s, a citizen is only regarded "individually concerned" and allowed to go to court, if he or she is affected like an addressee, thus in an "exclusive/unique/peculiar" way by a piece of EU law. Therefore, a year after the People's Climate Case is filed, on 8 May 2019, the European General Court - the Court of First Instance - dismissed the People's Climate Case by recognizing that plaintiffs are affected by climate change but they are not sufficiently unique to challenge the EU legislation. Even though the plaintiff families and the Saami youth had set out their individual concerns in detail, with regard to their property, farms and other businesses, as well as to their health and educational rights, these are not seen as "unique" enough by the European General Court.

As it stands, the Court's decision means that the more people are affected and the more serious the damage, the less they can have access to justice in the European Courts. This represents a major barrier to access to justice for individuals who are trying to challenge EU legislation on environmental grounds. 
This decision also disrespects the very rationale of fundamental rights, which is to grant protection to every single person, and disregards the seriousness and magnitude of the climate crisis addressed by plaintiffs. By the time this book is published (or sent to print), the plaintiffs are still seeking justice in the higher instance court, the European Court of Justice, by explaining why people affected by the climate crisis should be protected through the EU legal system.

Even though it is already shameful that families and indigenous youth from Europe and the Global South need to go court to urge the EU to step up climate action, all the time lost in the procedural battles to get their rights recognized - to simply enter courtrooms - proves that our legal systems should also be adapted to the magnitude of the ongoing climate crisis. We definitely need reinterpretation of existing laws to the context of climate change but, more urgently and importantly, we need the EU to step up climate action in an unprecedented way so that citizens would not need to go to courts to search for climate justice.

Time is pressing. Every day more and more people are hit by climate change-induced disasters. In summer 2019, heatwaves, droughts and forest fires were wreaking havoc once again in Europe. The European Union's Earth Observation Programme, Copernicus, announced that the entire Earth had experienced its warmest June on record in 2019. This announcement was followed by World Weather Attribution group, who stated that record-breaking temperatures that hit Europe were at least five times more likely to happen in the future due to climate change.

The EU must understand that all these climate disasters are not simply about numbers or scientific projections. Today, they are citizens' top concern. And people will keep mobilizing every possible way to protect their lives, livelihoods and human rights. They will not allow politicians to keep arguing for the status quo and failing to take unprecedented climate action.

As Martin Luther King said: "Our lives begin to end the day we become silent about things that matter".

\section{PEOPLE'S CLIMATE CASE LINKS}

Legal documents of the People's Climate Case may be found at https://peoplesclimatecase .caneurope.org/documents/. Accessed 26 August 2020.

More information about the plaintiffs may be found at https://peoplesclimatecase .caneurope.org/who-we-are/. Accessed 26 August 2020.

The full text of the Paris Agreement may be found at https://unfecc.int/files/essential background/convention/application/pdf/english_paris_agreement.pdf. Accessed $\overline{2} 6$ August 2020. 


\section{NOTE}

1. https://www.euractiv.com/section/climate-environment/opinion/a-question-of -legacy-eu-must-step-up-and-lead-on-climate/. 